Article

\title{
Design of a Pedagogical Model of Education for Environmental Citizenship in Primary Education
}

\author{
Teresa Monte * and Pedro Reis \\ Instituto de Educação, Universidade de Lisboa, Alameda da Universidade, 1649-013 Lisboa, Portugal; \\ preis@ie.ulisboa.pt \\ * Correspondence: teresamonte@edu.ulisboa.pt
}

Citation: Monte, T.; Reis, P. Design of a Pedagogical Model of Education for Environmental Citizenship in Primary Education. Sustainability 2021, 13, 6000. https://doi.org/ $10.3390 /$ su13116000

Academic Editors: Pedro

Vega-Marcote and Wim Lambrechts

Received: 28 April 2021

Accepted: 24 May 2021

Published: 26 May 2021

Publisher's Note: MDPI stays neutral with regard to jurisdictional claims in published maps and institutional affiliations.

Copyright: (c) 2021 by the authors. Licensee MDPI, Basel, Switzerland. This article is an open access article distributed under the terms and conditions of the Creative Commons Attribution (CC BY) license (https:// creativecommons.org/licenses/by/ $4.0 /)$.

\begin{abstract}
Education for Environmental Citizenship plays an important role in social change toward sustainable development, achieving economic, social, and environmental balance through informed, cooperative, and participative citizens. There are several pedagogical models with the potential to involve students in environmental activities, but no specific model suitable for primary education is found. This article describes the preliminary investigation phase of a Design-Based Research that resulted in the development of the first prototype of a Pedagogical Model of Education for Environmental Citizenship in Primary Education (students aged 6 to 10 years), in Portugal. This preliminary investigation phase was based on a systematic analysis and literature review on the topic (thesis, articles, projects, and curricular guidelines for primary education), seeking to answer the following research questions: (1) According to the current world characteristics, which learning outcomes should an environmental citizen achieve, and which of them can be promoted in primary education? (2) What are the most appropriate teaching methodologies and strategies for promoting environmental citizen learning outcomes in primary education? The methodology used is presented, and the proposed prototype is described, along with the desired learning outcomes that are considered necessary for the formation of an Environmental Citizen and the most appropriate methodologies and educational activities to promote them.
\end{abstract}

Keywords: education for environmental citizenship; primary school; design-based research; pedagogical model

\section{Introduction}

Environmental Citizenship is one of the most important factors to achieve both the Sustainable Development Goals for 2030 and the objectives of the EU's economic growth strategy for 2050. Education for Environmental Citizenship enhances the development of active environmental citizens, and given its importance, it must be promoted from the beginning of schooling, according to the principles of Environmental Education set out in the Tbilisi Declaration.

Recently, Hadjichambis and Reis [1] defined Education for Environmental Citizenship as the type of education that cultivates a coherent and adequate set of knowledge as well as the necessary skills, values, and attitudes that an environmental citizen must have in order to act and participate in society as an agent of change, in the public and private sphere, on a local, national, and global scale, through individual and collective actions, solving environmental problems, preventing the creation of new environmental problems, achieving sustainability, and developing a healthy relationship with nature.

Education for Environmental Citizenship is considered a type of continuous education that should start at an early age to create healthy environmental habits in everyday life toward global sustainable development [2-7]. It promotes the practice of citizen's environmental rights and duties and helps in the identification of the structural causes underlying environmental degradation, enhancing the development of skills for critical, 
active involvement and civic participation, considering inter- and intra-generational justice [8]. Primary education is the appropriate period for laying the foundation of children's future willingness to actively participate in responsible behaviour at both individual and collective levels, and children at earlier ages are more willing to participate and show better outcomes after educational interventions aimed at developing key values and skills for Environmental Citizenship $[7,8]$.

The integration of Education for Environmental Citizenship in the existing disciplines makes learning more meaningful, as it enables the acquisition of a better understanding of the contents covered from various areas of knowledge [9], promoting interdisciplinary cooperation and student motivation [9-11].

The main objectives of Education for Environmental Citizenship are: to promote student involvement with nature and the environment [1,12]; to promote the acquisition of responsible behaviors and attitudes of defense, environment preservation, and improvement in students daily lives; to promote students' scientific and environmental literacy; to promote active and informed participation in environmental issues by students at the individual and collective level; and to enhance sustainable development [1,12-14].

Since emotional, sensory, and intellectual components are always interconnected, it is necessary to raise the development perception and awareness of students to promote their involvement in a certain situation, event, or learning process $[15,16]$. In this specific case where one of the objectives is to involve students in issues related to the environment, it is essential to develop feelings such as respect, love, esteem, and empathy for nature and for all beings that cohabit in it (animals, plants), knowing the natural processes of evolution and maintenance, its resources (water, air, soils) and its characteristics, and understanding that they are all interconnected and that the Planet Earth is a community where everyone belongs [17-19]. With this involvement, students will be able to develop moral values, establish an emotional connection, and feel an environmental "moral obligation" that will lead them to adopt responsible and beneficial behaviors and attitudes in their daily lives $[17,19-21]$, contributing in some way to the defense, preservation, and improvement of nature and the environment.

With the acquisition of responsible behaviors and attitudes, the involvement and active participation of students in environmental issues in their socio-cultural environment is thus enhanced $[1,16]$.

Promoting knowledge and skills development in environmental sciences leads to a better understanding of environmental issues, thus enhancing guided, conscious, and informed participation by students. Participation in decision-making, from a social, economic, and environmental point of view, is one of the duties of individuals as citizens. When promoting students' active and informed participation, there is a call to action to solve and/or avoid environmental problems through informed decisions [8]. An informed student has a better understanding of socio-environmental and socio-cultural problems in his community, thus developing his critical thinking and decision-making [1,2,10,16,22-24]. For some authors [21,25], a high degree of environmental literacy along with environmental awareness promotes a vast scientific vocabulary that induces effective and assertive communication when engaging in civic participation in socio-environmental issues.

Achieving sustainable development is the major global objective regarding the economy, society, and the environment. An environmental citizen will be the one who, having an environmental conscience and knowledge, will tend to not only change his behaviors and attitudes to preserve the environment, but also participate actively in private or public initiatives contributing to achieving sustainable development $[1,10,16,21]$.

There are already several pedagogical models used to promote education for environmental citizenship; however, these models are general and without direct application in primary education. This investigation aims to achieve a pedagogical model suitable for primary education, and thus, in this article, the first prototype designed will be described, based on a systematic review of the literature found. 


\section{Methodology}

This study follows a Design-Based Research methodology, with a preliminary investigation phase and three iterations that allow the design, development, evaluation, and review of the prototype of the pedagogical model for primary education whenever necessary and in a real context.

The preliminary investigation phase described in this article is based on a literature review of the areas and aspects to be investigated regarding Environmental Citizenship (step 1) and in the development of a prototype (step 2).

In Step 1, and based on the documental analysis of thesis, articles, and projects related to education, citizenship, environment, educational methodologies in primary education, curricular guidelines proposed by the Ministry of Education in environmental studies, and community projects developed in primary education, the following research questions were answered:

(1) According to the current world characteristics, which learning outcomes should an environmental citizen achieve, and which of them can be promoted in primary education?

(2) What are the most appropriate teaching methodologies and strategies for promoting environmental citizen learning outcomes in primary education?

In Step 2, a prototype was developed based on the information obtained in Step 1.

The research was carried out initially using the Library Database of the Education Institute of the University of Lisbon, which contains the University of Lisbon Integrated Library System (SIBUL), the General Repository of the University of Lisbon, and the Scientific Repository of Open Access of Portugal (RCAAP), to research theses and other digital documents produced by Portuguese Universities and the EBSCO and B-ON portals to access full texts of international and national scientific journals. These portals ensure a thorough literature review. In addition, research was done using Google Scholar, the website of the Ministry of Education, and websites of Environmental Non-Governmental Organizations (ONGA). No criteria were defined in relation to the date of the documents searched; the only condition established was the presence of (at least) one of the following words in the title or in the body of the text: environmental citizenship; environmental citizen; education for environmental citizenship; primary education; educational pedagogies; education; environment; citizenship; sustainable development; education for sustainable development. All the documents identified in the databases were analyzed in a detailed way for relevant information connected to our study and according to the criteria presented in Tables 1 and 2. During this analysis, all double documents were excluded.

Table 1. Literature review process.

\begin{tabular}{|c|c|}
\hline \multicolumn{2}{|c|}{ Literature Review Process } \\
\hline Planning & $\begin{array}{l}\text {-Research objective identification } \\
\text {-Development of search criteria } \\
\text {-Selection of databases to be used }\end{array}$ \\
\hline $\begin{array}{l}\text { Information gathering, evaluation, and } \\
\text { prior analysis }\end{array}$ & $\begin{array}{l}\text {-Research, screening, and initial review } \\
\text {-Synthesis and characterization of studies } \\
\text { - Obtaining preliminary results }\end{array}$ \\
\hline Analysis and Interpretation & $\begin{array}{l}\text { - Detailed study of the documents obtained } \\
\text { - Analysis and interpretation of results }\end{array}$ \\
\hline Structuring & $\begin{array}{l}\text { - Structuring the information obtained } \\
\text { - Analysis writing and data results interpretation }\end{array}$ \\
\hline
\end{tabular}


Table 2. Criteria for document selection.

\begin{tabular}{l}
\hline \multicolumn{1}{c}{ Criteria for Document Selection } \\
\hline Educational proposals within the Education for Environmental Citizenship. \\
\hline $\begin{array}{l}\text { Implementation of Environmental Education initiatives in non-formal, informal, and formal } \\
\text { contexts (including environmental programs with the involvement of schools, family, } \\
\text { and community). }\end{array}$ \\
\hline Research and development of pedagogical models in Environmental Education \\
\hline $\begin{array}{l}\text { Research on issues such as attitudes, behavior, emotions, and decision making in primary } \\
\text { education regarding the environment. }\end{array}$ \\
\hline Studies on Environmental Education that present innovative pedagogical strategies. \\
\hline Research methods, theories, and research results within the scope of this project. \\
\hline
\end{tabular}

The literature review process is briefly described in Table 1.

This review process involved the selection of the documents that met the requirements defined in Table 2.

\section{Results and Analysis}

\subsection{Preliminary Investigation Phase-Step 1: Literature Review}

Based on the literature review, it was possible to establish a set of learning outcomes that should be acquired by an environmental citizen and the methodologies used to promote Environmental Citizenship in primary education.

\subsubsection{Environmental Citizen Competences}

Environmental awareness is considered by several authors [17,26-31] to be one of the most important characteristics of an environmental citizen. There is usually an effective change in behavior and/or attitude in an individual in two ways: when something is imposed on him, or when he identifies with something [15]. By having a perception of how ecosystems work, how they are maintained, their characteristics, and all interactions, students develop feelings of belonging and acquire a real concern and a natural involvement with the environment that surrounds them $[17,21,32,33]$. This environmental awareness can be developed with sensory activities and nature exposure through free games and play on a regular basis, and if possible, daily [21,34-36].

Environmental knowledge is another characteristic found in the literature and concerns mainly the development of three knowledge forms-namely, action-related knowledge, effectiveness knowledge, and system knowledge [37]—which can be developed through formal, non-formal, and informal education. Knowledge is considered a prerequisite for action and decision making in a conscious and informed way [1,38-40]. According to our literature analysis, the development of environmental knowledge must be carried out based on real situations easily identified by students and preferably linked to the environment where they live and within the community $[1,41,42]$.

Each student, whether a child or young person, has personal characteristics that are intrinsic and that should be considered when applying a particular pedagogy [43]. However, according to our analysis, some personal skills such as communication, critical thinking, and creativity can be developed or worked on, enhancing active participation in environmental activities [44-46]. Activities such as project/research work or in pairs can help students in their development and in the acquisition of a sense of personal, social, and environmental responsibility.

Culture and social environment are important factors in learning because there are normative values and rules conditioning the behavior and attitudes of individuals due to their personal and educational background [40,47]. In our analysis, it emerged in a clear way that the development of socio-cultural competences, such as responsibility, justice, and equity, promote the acquisition of pro-environmental behaviors and attitudes 
in our daily lives and are closely linked to the rights and duties of an environmental citizen $[1,26,27,48,49]$.

All human beings have the right to live in a healthy environment and free from pollution, but on the other hand, they have a duty to protect the future of the next generations, to be informed about environmental problems, to participate in conservation and preservation initiatives, and engage in environmental practices in their daily lives $[26,27,46,48,50]$. All citizens are considered agents of change, and this also applies to children, who have a duty to act to preserve the environment, finding solutions to existing environmental problems and preventing other problems that may arise [1,40,49].

According to Hadjichambis and Reis [1], an environmental citizen has a coherent and adequate set of knowledge, as well as the skills, values, and attitudes necessary to be able to act and participate in society as an agent of change, in the public and private sphere, on the local, national, and global scale, through individual and collective actions aimed at solving contemporary environmental problems, preventing the creation of new environmental problems, achieving sustainability, and developing a healthy relationship with nature. An environmental citizen is an individual who practices his environmental rights and duties, can identify the structural causes underlying environmental degradation and environmental problems, and has the skills for critical and active involvement and civic participation to address these structural causes and to act individually and collectively within democratic circles, taking inter and intra-generational justice into account [51].

Figure 1 briefly elucidates the learning outcomes that are deemed necessary for the practice of Environmental Citizenship according to what was previously mentioned.

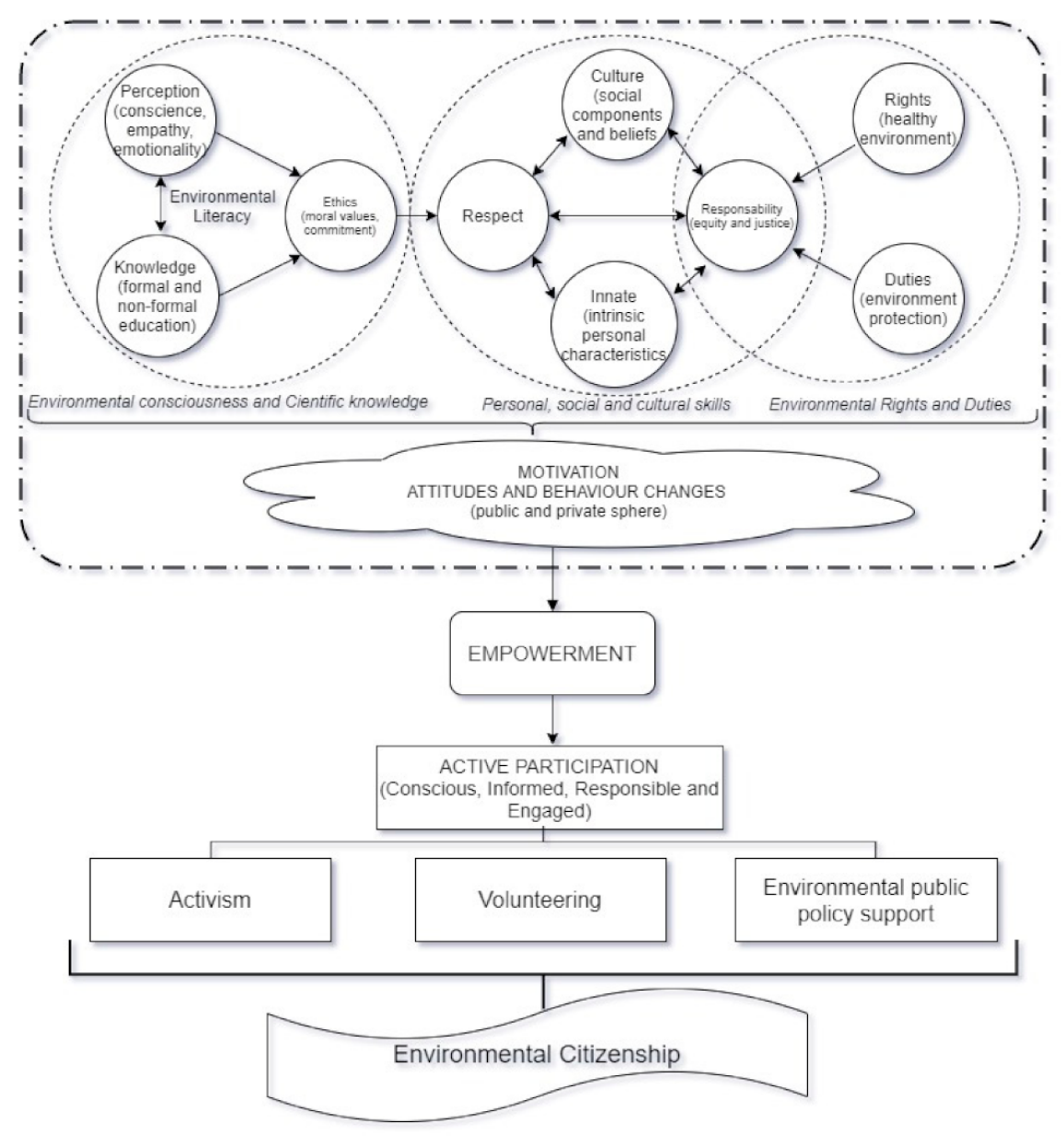

Figure 1. Environmental citizen learning outcomes. 
An environmental citizen has an environmental awareness and knowledge about nature and the environment, so he will not only tend to change his behaviors and attitudes to preserve the environment but will also participate actively in private or public initiatives to improve the environment through actions of activism, volunteering, and supporting environmental public policies $[1,13,14]$. Those actions are triggered by an empowerment acquired through several school experiences where skills such as trust and motivation are developed. The students empowered reveal, in general, decision-making autonomy and a great involvement in environmental activities [52].

In environmental activism actions, it is assumed that individuals are involved and committed to public actions, influencing the behavior of the population in general and the public policy system, participate in environmental events, and have an active involvement in environmental organizations to achieve socio-environmental change and the common good [14]. According to Marques and Reis [46,53], the involvement of students in the development of activism initiatives promotes the acquisition of critical thinking skills, communication, creativity, perseverance, empowerment, and the perception that they can create change in the world.

For Reis [54,55], activism is an important aspect of environmental citizenship, allowing citizens to become active participants rather than simply spectators who depend on the opinions of experts. The involvement of students in activism initiatives represents a key element in Education for Environmental Citizenship, creating an excellent context for the development of knowledge, skills, values, and attitudes that "empower" citizens as agents of change, capable of conceiving and implementing individual and collective actions aimed at solving contemporary environmental problems [8]. Youth activism initiatives allow students to exercise their environmental rights and duties, understand the causes of environmental problems, and develop the skills necessary to develop solutions. According to the same author, through activism actions, students move from a learning position to a new position, with involvement in citizenship and scientific research practices, increasing the potential to strengthen ties between schools and the communities where they live, students, and their families.

In the case of volunteering, individuals are able to participate, for example, in reforestation and cleaning actions and be present at fairs and festivals to publicize environmental activities and themes for the defense and preservation of the environment, supporting causes both socially and culturally that benefit the place where they are located and/or contributing with funds to environmental organizations [14].

Supporting environmental public policies essentially concerns the interest in environmental actions carried out by the government, through the exercise of the right to vote, signing environmental petitions, and behavior change as a consumer, in the case of reducing the use of energy, purchasing products that are "environmentally friendly", plastics reduction, and recycling, among others [14].

Students' motivation is acquired by the perception that their actions can help "to relieve" the environmental threats and restore the socio-environmental values lost, which will enhance their active participation for the social common good, as a part of their own identity [14].

\subsubsection{Methodologies to Promote Education for Environmental Citizenship}

Currently, there are several methodologies with the potential to integrate environmental citizenship in a school context, giving students the opportunity to become agents of change in their local community and preparing them to actively contribute to a sustainable future, achieving empowerment.

The approach known as Ecopedagogy by Paulo Freire $[39,56]$ defends a school curriculum that links the teaching and learning of environmental concepts to citizenship education. According to this perspective, aimed to involve citizens in environmental issues, participatory pedagogy should be adopted, giving relevance to students' collaboration 
and involvement in the understanding of the environmental causes and consequences and presenting solutions for them.

Action-oriented learning is one of the most used approaches in the educational process to promote the resolution of socio-environmental issues and to enhance decisionmaking [1,57]. According to Jensen [57], this type of learning is based on practical and scientific activities and oriented towards the social sciences, enhancing motivation, interest, and the acquisition of knowledge, promoting a real change in behavior in relation to environmental and/or social problems.

Problem-based learning (PBL) is a socio-constructivist teaching-learning strategy, through which students solve real socio-environmental problems while they gain knowledge about the subjects in question [58]. In this approach, students use their own knowledge and experiences to solve real-life problems. According to several authors $[59,60]$, in problem-based learning, various real-life scenarios are introduced as a starting point for the learning process in which students acquire critical thinking, collaboration, respect, leadership, autonomy, and responsibility.

Recently, there has been a growing interest in the use of collaborative learning activities in almost all teaching-learning contexts. Collaboration has become an important work strategy in the world of education, especially in the development of curricular projects and carrying out educational intervention projects focused on specific problems, such as environmental problems [61-63]. This methodology proved to be a promising strategy for educators to use in primary education [64].

Over the past few decades, socio-emotional learning has been the subject of research, realizing that socio-emotional interactions are essential in the learning process [65-67]. Several studies have shown that emotions are an integral part of learning, influencing student's motivation, cognitive processes, and performance [68-70]. Through socio-emotional learning, it is intended to establish trust and collaborative relationships through associations between school, family, and community, addressing various forms of inequality and enabling children, young people, and adults to co-create prosperous schools and contribute to safe, healthy, and fair communities $[67,71]$.

Critical inquiry learning is another constructivist and student-centered, practical, and integrated approach that promotes the development of scientific and technological competences, thereby enhancing informed, responsible, democratic, and critical decisionmaking concerning environmental issues [72].

For Bai [73], environmental education must start with the valuation of the world intrinsically, placing the senses at the center of consciousness, instead of continuing in what he calls "abstract linguistic-conceptual mode". In this way, contemplative practices may ultimately be a vehicle for social change, leading to actions of activism, since the awareness of oneself and the others will make students get involved and participate in social justice activities and social causes volunteering [74]. In the context of environmental education, contemplative learning is relevant, because through various exercises, such as yoga and/or mindfulness, among others, students learn to respect their body and senses, understanding life as an integral part of nature [75].

Other methodologies found in the literature refer to community-based learning that combines educational objectives with community service and can provide students with opportunities to make relevant and authentic contributions to the improvement of local environmental issues and to act as responsible citizens [76]. Interactions with the community can raise students' concerns regarding social justice and equality, making them aware of the impact of social and environmental issues on the community and motivating them to actively participate and become agents of change $[77,78]$.

According to Weisberg et al. [79,80], play-based learning is a methodology that involves playful activities, guided by the teacher, and specific learning objectives to promote the cognitive, emotional, and social development of children. Involvement in games/play encourages children to acquire skills such as imagination, creativity, curiosity, enthusiasm, 
persistence, exploration, and discovery, enhancing the development of socially competent students capable of facing challenges and creating solutions in their everyday life [81].

On the other hand, outdoor learning promotes understanding, and the acquisition of knowledge by the student himself, motivated by his natural curiosity [16,82-85], promoting his involvement and behavior change related to nature and the environment $[16,36,85,86]$. For Kuo [87], experiences in nature help students acquire the skills needed by a citizen of the 21 st century and that are necessary to make decisions when they actively participate in society.

The recent nature-based solutions (NBS) are economic solutions supported and inspired by nature while providing environmental, social, and economic benefits and helping to build resilience [88]. These solutions recreate in the cities, and in maritime landscapes, natural and diversified characteristics and processes of nature, through systemic interventions, efficient in terms of resources and adapted locally, to benefit biodiversity and combat climate change, among others. There are several learning scenarios developed for the application of NBS, promoted by the European Commission, namely for primary education [89-92].

Hawthorne and Alabaster [40] developed and tested a pedagogical model to achieve environmental citizenship, based on the interrelationships between the components defined "a priori". These components that integrate environmental citizenship include environmental information, environmental awareness, environmental concern, attitudes/beliefs, education and training, knowledge, skills, environmental literacy, and responsible behavior. This model indicated that participation in environmental education and training is the most important prerequisite for environmental behavior, followed by emotionality. However, the complexity of the interactions (Figure 2) that determine behavior illustrates that environmental citizens are not promoted only by education programs, but by a whole set of factors with which education has to interact, such as personal and personality factors that have a strong influence on behavior change.

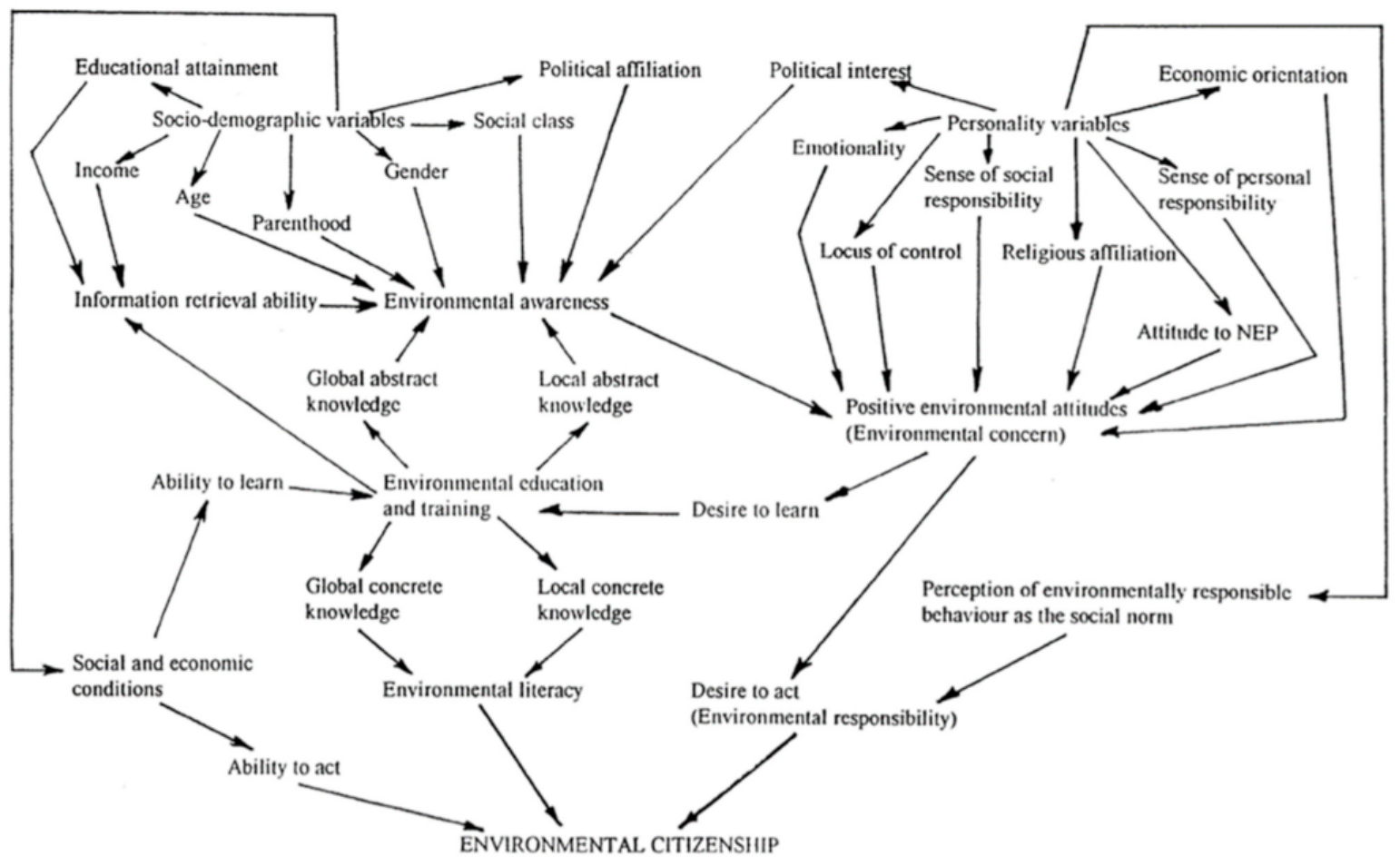

Figure 2. Pedagogical model to achieve environmental citizenship [40] (p. 30).

Recently, Hadjichambis and Paraskeva-Hadjichambi [93], developed a holistic pedagogical model of Education for Environmental Citizenship. In their pedagogical model, 
the starting point is a local environmental problem based on the interests and concerns of the students, which the students feel that they have the responsibility to solve, because it is a problem faced by their community. It may be also a global environmental problem, reflected locally, making students feel capable of acting as agents of change. Student's interests can be stimulated through photos, videos, and controversial news. This model includes six (6) steps: research, action planning, critical and active involvement and civic participation, networking and information sharing on a local, national, and global scale, environmental and social change, and evaluation and reflection. According to the authors, the steps are not in a linear sequence, and an entry point can be any of the six, which include different sub-steps, all integrating Education for Environmental Citizenship (Figure 3).

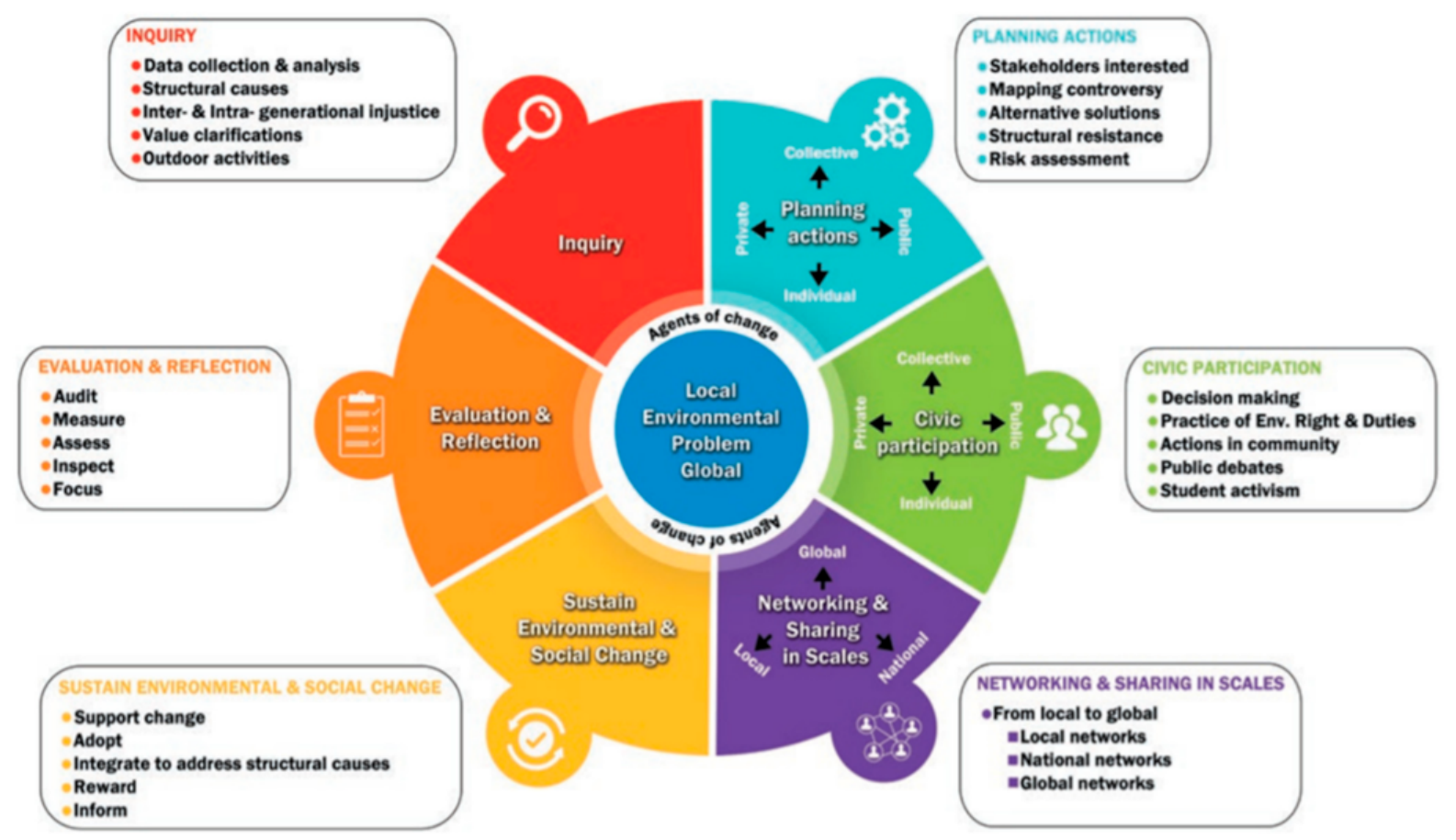

Figure 3. Pedagogical model for Environmental Citizenship Education [93] (p. 251).

\subsection{Preliminary Investigation Phase-Step 2: Development of the Prototype}

The development of the prototype was based on a literature review regarding Education for Environmental Citizenship.

In this prototype, an environmental citizen is defined as a conscious, engaged, informed, and empowered individual with knowledge of the current political and socioenvironmental panorama, which includes his rights and duties as a citizen, who respects the environment, others, and himself, feels the responsibility and moral duty to act and change his behavior and attitudes, promoting the common well-being of all, and whose individual or collective actions, whether social activism, volunteering, or political-social, contribute to achieving environmental sustainability in his community and in the world. Thus, it is intended to develop in students the following learning outcomes: awareness and consciousness, knowledge, rights, duties, critical thinking, ethics, respect, responsibility, and empowerment. In this way, the methodologies selected are those that the author believes are best suited for the development of the environmental citizen learning outcomes, mentioned above, in primary education.

\subsubsection{Methodologies in the Prototype}

The principles of Environmental Education, set out in the Tbilisi Declaration, include fundamental elements for sustainable development, such as the need to consider socioenvironmental aspects and consider the relationship between economy, environment, and 
development, adopting local and global perspectives, and the promotion of international solidarity [94]. In this way, Environmental Education should have cognitive, affective, and participative components, whose objective should not be limited to the development of knowledge and awareness of environmental problems, but also to dedicate itself to the development of appropriate characteristics and to promote the future participation of students in decision-making, as citizens in their local communities [45]. According to Orr [95], "all education is environmental education", and as environmental issues are complex and global, they cannot be understood through a single discipline and must function as an interdisciplinary theme, using integrated pedagogies.

One of the objectives of environmental education is precisely to promote environmental citizenship [1,96-100]. In this way, a new model of education emerged based on research and action, together with civic involvement, more appropriate for the promotion of the type of citizenship and literacy necessary for sustainable development, also known as Education for Environmental Citizenship [42,96]. Education for Environmental Citizenship, in addition to enhancing social skills and scientific knowledge, also incorporates a more interdisciplinary socio-environmental understanding, promoting results oriented to action and decision-making, which differs from conventional education $[38,39]$.

Currently, there are several constructive, collaborative, critical, and reflective methodologies with great potential for integrating Environmental Citizenship in a school context and giving students the opportunity to become agents of change and preparing them to actively contribute to a sustainable future. Generally, those that involve the cognitive domain, the psychomotor domain, and the affective domain are considered the most relevant and effective, as they allow students to develop sustainability skills [101,102].

Education for Environmental Citizenship, being considered a type of interdisciplinary, formal, informal, and non-formal education, which encompasses several types of pedagogies, strategies, and educational methods and which promotes lifelong learning, must be approached from a perspective that integrates the entire curriculum, enabling students to understand the relationship between socio-environmental issues, socio-political actions, and the local, national, and global environmental effects in today's society.

Bearing in mind that education is an active process that lasts a lifetime, it is understood that there will not be a single pedagogical model that is valid for all circumstances, and the methodologies to be adopted for the involvement of children in these themes must be flexible and adapted, especially for young children [2,103]. Such methodologies, which are sometimes intuitive, necessarily must consider the child's individuality, situational contexts, and the relationship that is formed between the child and the teacher, because strategies that are appropriate for one child may not be appropriate for another [43].

Figure 4 shows the methodologies that were considered for this prototype according to the ages and the cognitive maturity of the students.

Collaborative learning is a particularly important strategy for carrying out educational intervention projects focused on environmental problems [61-63]. Following this learning, collaboration between students is promoted, and the development of interpersonal, social, and communicative skills, such as critical thinking, motivation, self-esteem, confidence, and respect for others, increases productivity and self-realization [62,104-109]. With this learning, it is intended to encourage students to acquire an active voice in the formation and communication of their ideas and values through dialogue, discussion of points of view, construction of solutions, and decision making based on the differences of the members of the group, which may motivate them toward civic participation in environmental issues. It has already been demonstrated through some studies $[64,110]$ that this approach is a promising strategy to be used in primary education. 


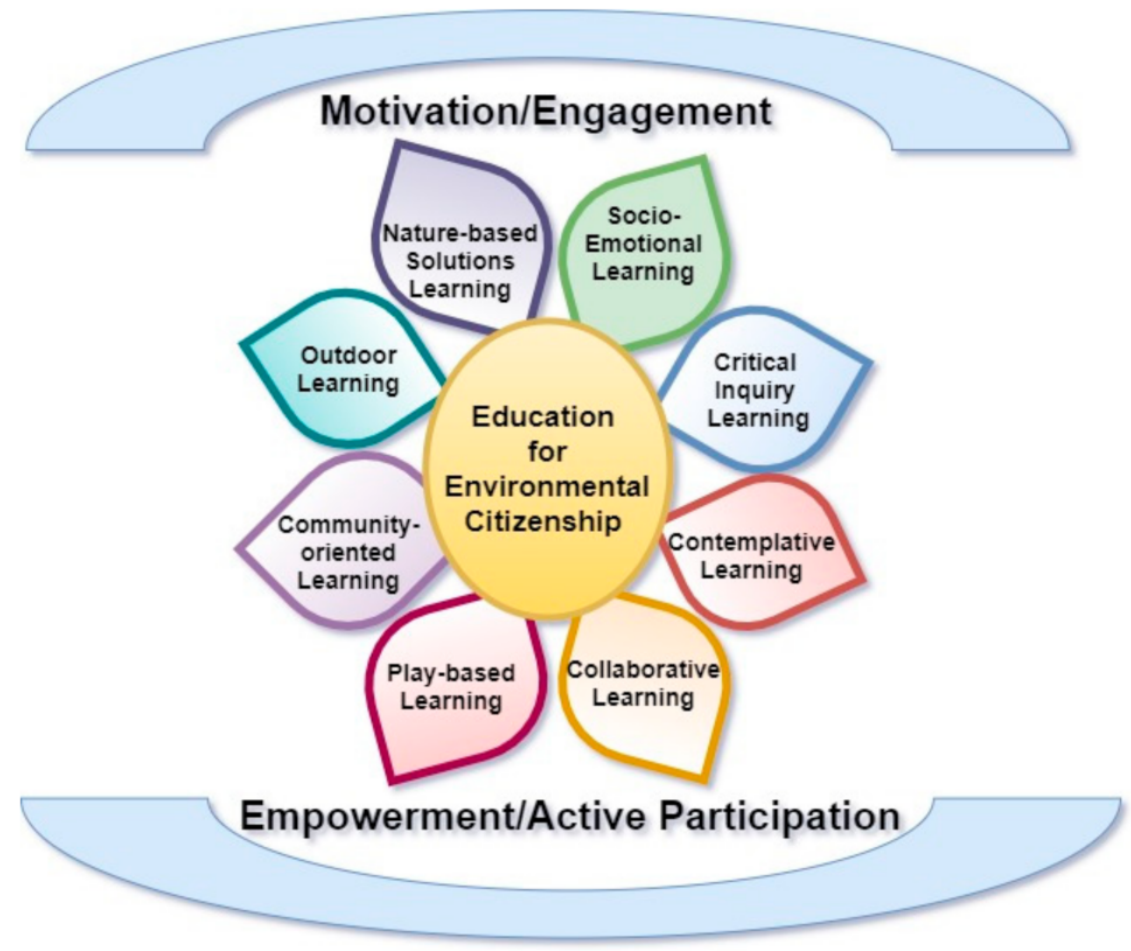

Figure 4. Methodologies to be adopted in the pedagogical model of Education for Environmental Citizenship in primary education.

Socio-emotional learning is a process that helps children to develop their identity, understand and manage emotions, define and achieve personal and collective goals, feel and show empathy for others, establish and maintain positive relationships, and make responsible decisions $[67,71]$, so it is considered an important strategy to adopt in this prototype. Through socio-emotional learning, it is intended that students acquire self-awareness, self-management, social awareness, inter-help, and responsible decision-making competences $[67,111]$. According to some studies, [112,113], this methodology is highly effective in younger children, because it is at this stage that their behaviors are most malleable and moldable. One of the main objectives of the primary education curricula is precisely to enhance social and emotional development of students, in addition to developing their scientific and environmental literacy, so it is crucial to acquire socio-emotional skills to promote student's attention and improve memorization and self-regulation through their involvement and motivation $[71,114,115]$.

Considering that the first years of schooling are crucial in the student's involvement in the teaching-learning process and in the construction of knowledge in the most diverse areas, learning by critical inquiry is important for the effective motivation of the student due to his natural curiosity, developing key competences, namely, critical thinking and scientific reasoning, through more practical and integrated learning, enhancing informed, responsible, democratic, and critical decision-making [72,116]. Critical inquiry learning is widely used in Science Education at all levels, enhancing the interest, involvement, and satisfaction of students during the learning process [116,117].

Contemplative learning challenges traditional approaches and it was introduced in this prototype as it is an innovative pedagogy and a useful technique for students to develop attention, emotional balance, empathy, compassion, and altruistic behavior while promoting creativity and learning motivation [118-122]. In the context of Environmental Education, this pedagogy is relevant because students learn to respect the body and the senses, understanding life as an integral part of nature [75], promoting the genuine perception that individuals belong to an ecological community $[123,124]$. It is intended that contemplative practices cause a change in students' promotion of activism, because 
the awareness of oneself and the others and the feeling of unity with Nature, combined with a deep sense of ecological injustice, will cause students' involvement and participation in social justice activities and volunteering in social causes $[74,125]$. Thus, the implementation of contemplative practices such as mindfulness and/or yoga is suggested to enhance the success of an education for environmental citizenship and consequently for sustainable development.

Community-oriented learning not only promotes ties with the community, but also enhances a greater appreciation for the natural environment, providing students with the opportunity, to analyze, criticize, and improve local environmental practices [126,127], raising concern regarding socio-environmental injustices, making them aware of the impact of social and environmental problems on the community, and motivating them to active participation [78,127]. In this way, students develop their sense of justice, equity, responsibility, and critical and creative thinking, important characteristics of active participatory citizenship [1,21,127-131].

Through play-based learning, critical thinking, creativity, competence for problem solving, the formulation of hypotheses, the understanding of concepts, and the ability to make decisions are promoted [132-134]. In this context, children can explore, experiment, discover, and solve problems in a creative, imaginative, and playful way [133], developing social skills and making students capable of facing and creating solutions to challenges in their daily lives [82].

When it comes to Education for Environmental Citizenship, the first methodology that occurs is undoubtedly nature-based learning or outdoor learning. Through naturebased learning, the development of student's motivation is promoted through feelings of connection to nature in combination with the acquisition of environmental concepts, which effectively produces an involvement and change in authentic ecological behavior $[16,36,85,86,135]$. Contact and experience in and with nature improve student's attention, lower stress levels, and promote self-discipline, interest, and pleasure in learning, while providing a calm, quiet, and safer context for learning. They help students to acquire the skills needed by a citizen of the 21st century and that are necessary for decision-making within a real-world scenario when participating actively in society $[87,136,137]$. The combination of nature observation, together with the knowledge acquired in the classroom, is a powerful methodology, especially when it allows students to understand the impact of human action on wildlife and natural habitats [138], functioning in this way as a catalyst for cognitive and experiential learning, especially at earlier ages [36,82,84,86,138].

Although recent, learning through nature-based solutions (NBS) proved to be a promising strategy for educators to use in primary education [89,92]. The application of nature-based solutions (NBS) in the classroom enhances the development of environmental citizenship skills, such as creativity, problem solving, decision making, collaboration, environmental awareness, social justice, respect, and responsibility, and in addition increases environmental and scientific knowledge and the active participation of students. When NBS initiatives are promoted, students become aware of ecosystems, whose relationships can help in adapting to climate change, protecting biodiversity, integrated water resources management, and reducing the risk of environmental disasters [139]. NBS offers the advantage of promoting interventions with economic, social, and environmental benefits, promoting a greener, fairer, more equitable, and more efficient economy and a more resilient society $[88,140]$. Students "working with nature" and "innovating with nature" can benefit from ecosystems, providing flexible, economical, and widely applicable alternatives to deal with climate change among other environmental problems [140]. Nature-based solutions can and should be used together with other types of interventions to maximize their effectiveness.

Table 3 shows the desired learning outcomes that are developed for each learning pedagogy according to the prototype of a pedagogical model for Environmental Citizenship in primary education. 
Table 3. Learning pedagogies vs. desired learning outcomes according to the prototype of a pedagogical model for Education for Environmental Citizenship in primary education.

\begin{tabular}{|c|c|c|c|c|c|c|c|c|c|}
\hline \multirow[b]{2}{*}{$\begin{array}{l}\text { Learning } \\
\text { Pedagogies }\end{array}$} & \multicolumn{9}{|c|}{ Desired Learning Outcomes } \\
\hline & $\begin{array}{l}\text { Environmental } \\
\text { Consciousness }\end{array}$ & $\begin{array}{l}\text { Environmental } \\
\text { Knowledge }\end{array}$ & $\begin{array}{c}\text { Environmental } \\
\text { Rights }\end{array}$ & $\begin{array}{c}\text { Environmental } \\
\text { Duties }\end{array}$ & Respect & Responsibility & Ethics & $\begin{array}{c}\text { Critical } \\
\text { Thinking }\end{array}$ & Empowerment \\
\hline $\begin{array}{l}\text { Collaborative } \\
\text { learning }\end{array}$ & & & & & $\times$ & $\times$ & & $x$ & \\
\hline $\begin{array}{l}\text { Socio- } \\
\text { emotional } \\
\text { learning }\end{array}$ & $\times$ & & $x$ & $x$ & $\times$ & $x$ & & & \\
\hline $\begin{array}{l}\text { Critical inquiry } \\
\text { learning }\end{array}$ & $\times$ & $\times$ & & & & $x$ & & $x$ & $x$ \\
\hline $\begin{array}{l}\text { Community- } \\
\text { oriented } \\
\text { learning }\end{array}$ & & & $\times$ & $x$ & & $x$ & $\times$ & & $x$ \\
\hline $\begin{array}{l}\text { Play-based } \\
\text { learning }\end{array}$ & $\times$ & $\times$ & & & $x$ & $x$ & & $\times$ & \\
\hline $\begin{array}{l}\text { Contemplative } \\
\text { learning }\end{array}$ & $\times$ & & $x$ & $x$ & $x$ & & & & \\
\hline $\begin{array}{l}\text { Outdoor } \\
\text { learning }\end{array}$ & $x$ & $\times$ & & & $\times$ & $\times$ & $\times$ & & \\
\hline $\begin{array}{l}\text { Nature-based } \\
\text { solutions } \\
\text { learning }\end{array}$ & $\times$ & $x$ & & & $\times$ & $x$ & & $x$ & $\times$ \\
\hline
\end{tabular}

\subsubsection{Educational Activities}

In this prototype, the proposed educational activities were developed considering the curricular guidelines and the contents of the discipline of environmental studies, as well as the model of operationalization of the Citizenship and Development curriculum in primary education developed by the Ministry of Education in Portugal.

The main objectives to be developed through these activities are as follows: develop student's awareness and sensitivity about local, regional, and global environmental problems; increase environmental and scientific literacy that enables a greater understanding of nature and the environment, potential problems, and associated threats; promote behavior and attitude changes that encourage feelings of empathy, concern, and protection of nature and the environment; develop social, personal, and communication skills that can help students, individually or as a group, to identify and seek solutions to environmental problems; promote students' active participation and involvement in socio-environmental issues; recognize the importance of reducing the production of solid urban waste; identify the " $5 R$ policy" (Refuse, Reduce, Reuse, Repurpose, Recycle) and recognize its importance in the management of urban solid waste; separate all urban solid waste for recycling and/or composting; distinguish between renewable and non-renewable energies and know their importance for the preservation and conservation of the environment and nature; identify different types of pollution and/or other environmental problems in the local community; identify the main threats to animal and plant species and understand the importance of preserving biodiversity; recognize the importance of water, air, and soil quality, understanding the need for preservation; recognize environmental changes such as deforestation, fires, and silting, and identify their consequences for the environment and living beings; mitigate climate change; develop solutions and actions to the current environmental problems.

Table 4 presents examples of educational activities proposed for the implementation of this prototype in primary education. 
Table 4. Educational activities proposed for the implementation of this prototype in primary education.

\begin{tabular}{cc}
\hline Proposed Activities & Pedagogies that Can Be Used \\
\hline $\begin{array}{c}\text { Plantation of native species around school } \\
\text { and in public places. }\end{array}$ & $\begin{array}{c}\text { Nature-based solutions learning } \\
\text { Nature-based learning (Outdoor) }\end{array}$
\end{tabular}

Construction of vertical and/or roof gardens at school and promotion of these gardens in students' homes and in community public places, like libraries, in collaboration with the Municipal Council.
Nature-based solutions learning

Nature-based learning (Outdoor)

Community-oriented learning Socio-emotional learning

Desired Learning Outcomes

environmental consciousness and knowledge

respect, responsibility, ethics critical thinkingempowerment

environmental consciousness and knowledge

respect, responsibility, ethics critical thinking empowerment

environmental duties and rights

Realization of community exhibitions and markets in collaboration with scientists, environmentalists, agronomists, farmers,

NGOs, and environmental centers concerning climate change adaptation.

Creation of networking and online platforms in collaboration with other schools in the region/country.

Collaborative learning Socio-emotional learning
Collaborative learning

Community-oriented learning Socio-emotional learning

environmental consciousness environmental duties and rights respect, responsibility, ethics critical thinkingempowerment

environmental consciousness environmental duties and rights respect, responsibility critical thinking

Study visits to natural areas and field activities for fauna and flora observation of the surrounding area, as well as identification of threatened species.
Nature-based learning (Outdoor) Socio-emotional learning Play-based learning Contemplative learning
Waste separation games from a set containing packaging, papers, bottles, fruit peels, batteries, oils, and other waste from school.

Conducting a composting point at school and in community, together with the Municipal Council.
Play-based learning

Collaborative learning

environmental consciousness and knowledge

respect, responsibility, ethics critical thinking empowerment environmental duties and rights environmental consciousness and knowledge respect, responsibility critical thinking

environmental consciousness and knowledge

respect, responsibility, ethics critical thinking empowerment environmental duties and rights

environmental consciousness and

Poster exhibition in schools, museums, and municipal libraries with measures to save electricity and water.
Critical inquiry learning Community-oriented learning

Socio-emotional learning
Cleaning campaigns in school outdoor spaces and surroundings together with community institutions and the Municipal Council.
Nature-based learning (Outdoor)

Community-oriented learning knowledge
respect, responsibility, ethics
critical thinking
empowerment
environmental duties and rights

environmental consciousness and knowledge

respect, responsibility, ethics empowerment

environmental duties and rights

environmental consciousness and knowledge

respect, responsibility critical thinking environmental duties and rights
Dynamics of yoga and/or mindfulness activities through children's stories and games, in collaboration with elderly homes.
Contemplative learning

Play-based learning

Socio-emotional learning 
Table 4. Cont.

\begin{tabular}{|c|c|c|}
\hline Proposed Activities & Pedagogies that Can Be Used & Desired Learning Outcomes \\
\hline $\begin{array}{l}\text { Identification of specific urban } \\
\text { environmental issues in the community, } \\
\text { choosing situations that most concern them, } \\
\text { like social inequality and poverty, and } \\
\text { acting to improve them, presenting their } \\
\text { solutions to local authorities. }\end{array}$ & $\begin{array}{l}\text { Critical inquiry learning } \\
\text { Collaborative learning } \\
\text { Socio-emotional learning }\end{array}$ & $\begin{array}{l}\text { environmental consciousness and } \\
\text { knowledge } \\
\text { respect, responsibility } \\
\text { critical thinking } \\
\text { empowerment } \\
\text { environmental duties and rights }\end{array}$ \\
\hline $\begin{array}{l}\text { Creation of a "laboratory-garden" in } \\
\text { collaboration with the Municipal Council, } \\
\text { community, and NGOs. }\end{array}$ & $\begin{array}{l}\text { Nature-based solutions learning } \\
\text { Critical inquiry learning } \\
\text { Collaborative learning } \\
\text { Community-oriented learning } \\
\text { Socio-emotional learning }\end{array}$ & $\begin{array}{l}\text { environmental consciousness and } \\
\text { knowledge } \\
\text { respect, responsibility } \\
\text { critical thinking } \\
\text { empowerment } \\
\text { environmental duties and rights }\end{array}$ \\
\hline
\end{tabular}

The proposed activities like vertical and roof gardens will improve air quality, reduce heat stress, and isolate the buildings, resulting in less energy use and lower costs, contributing in this way to mitigate climate change. On the other hand, creating social vegetable plots, maintained and managed in a sustainable way by local voluntary citizens, will strengthen community bonds, while vegetables and fruits can be distributed to the less favorable people, increasing social justice, equity, and social inclusion.

It is necessary to connect nature, science, and art, and this can be done through "laboratory-gardens", where it is possible to demonstrate sustainable agricultural techniques, enhancing the exchange of knowledge, skills, mutual help, and dialogue, through educational activities and workshops for the whole community.

Activities between students and the Municipal Council help to encourage the civic participation of children in the development of interactive initiatives for sustainable development together with community. In addition, these initiatives also aim to enrich the school program with curricular and extracurricular activities ranging from environmental education to active citizenship, and can be promoted in primary education, adjusted for each year and to specific contexts.

Proposing actions and demonstrating their impact on the community to the Municipal Council and other independent parties like NGOs will facilitate the resolution of problems from the bottom up, while promoting student engagement in scientific and policy processes. Thus, it creates links between education, science, and politics, strengthening the community and allowing students to participate in authentic problem solving of environmental issues from their direct surroundings and representation in socio-political actions, strengthening their environmental citizenship.

\subsubsection{Prototype Stages}

When talking about a pedagogical model, the elaboration of steps/stages for its construction is assumed. In this prototype, the stages are mainly based on the 5 Es of the project/investigation work presented by Bybee [141]; engagement, exploration, explanation, elaboration, and evaluation. When all stages are applied, it is expected that students acquire characteristics that an environmental citizen should have and that they manifest good practices of environmental citizenship.

Figure 5 shows a scheme with the stages of the prototype that are considered necessary for the promotion of Education for Environmental Citizenship in primary education. 


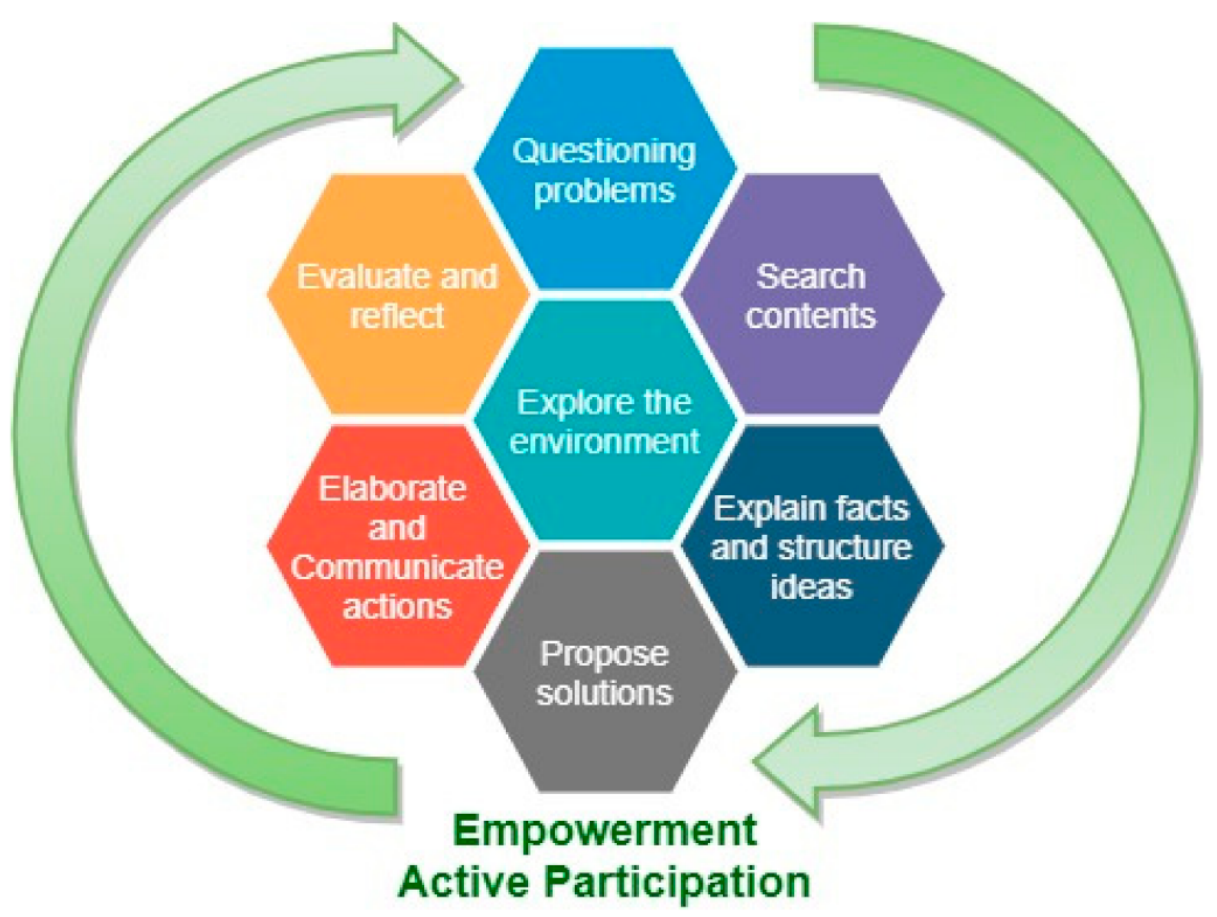

Figure 5. Stages considered in the prototype of a pedagogical model for Education for Environmental Citizenship in primary education.

Several studies show that contact with nature during childhood has positive effects throughout life regarding environmental issues, and according to Asah [32], children's self-exposure to nature is the factor that most contributes to environmental citizenship. At this stage, it is intended that students perform an autonomous and independent exploration of nature, as well as observe plants, animals, and other elements present and their relationships, in a free, spontaneous, and interested way. In this way, teachers/educators should interfere as little as possible in the way children experience nature, giving them the necessary freedom and accepting their choices while also guaranteeing their safety [142]. Thus, they will have the opportunity to create a connection with nature and perceive the existing relationships between all those who live in it, whether living beings or not [17], in addition to developing their personal and social skills, such as sharing, negotiating, resolving conflicts, working in groups, exercising self-defense, creativity, and autonomy [142,143]. Activities such as outdoor walks, visits to educational farms, picnics, or simply playing outdoors are the proposals of this stage. It may eventually be suggested to them to collect some plants, flowers, and other elements present in the place, according to their choices. To be effective, this step must be provided to students as many times as possible and on a regular basis [143].

The survey of environmental issues or problems should arise spontaneously, or if not, it should be proposed by the teacher who will guide students in searching for solutions for the problems found. At this stage, questioning problems, there is a call for individual action in terms of behavior change, as well as collective action. The activities that can promote this stage should be video and image views, sharing of experiences by the students, and knowledge about local community projects related to local environmental problems. The search for content stage can be carried out at the same time using information and communication technologies and consultation of books, newspapers, and magazines.

It is up to the teacher/educator to provide the appropriate material to stimulate communication and dialogue between students, using strategies such as educational games, films, or images. At the explaining facts and structuring ideas stage, it is intended that students share their experiences and perspectives, stimulating their communication regard- 
ing nature and the environment and developing their knowledge, based on observation, comparison, and analysis of similarities and differences, structuring their ideas in this way.

The development of solutions based on issues or problems related to nature and the environment must be fully carried out by the students and should also attend the inherent economic viability. Students should be the main actors, and the teacher should only guide and advise them throughout the process. Students who engage in environmental activities that benefit their community learn while addressing issues of social and environmental justice. Children have the right to act on local environmental problems that concern them and should be encouraged to engage in practical activities that include, in addition to research, the implementation and communication of actions, thus becoming active participants in all the processes.

The evaluation of the actions carried out, as well as their implementation in the school and in the community, is the last proposed step, in which it is intended that students reflect on the effectiveness of the solutions found for environmental problems and are able to show feasible alternatives for the protection of the environment, considering their participation from the beginning until the implementation of the actions that they propose and elaborate.

\section{Final Considerations}

Climate change, threats to biodiversity, and the reduction of natural resources, among other environmental problems, placed the topic of sustainable development on the world agenda as a priority, leading global efforts to develop several strategies to achieve it, thus ensuring environmental sustainability.

Environmental citizenship appears as a complementary way to promote sustainable development, and according to some economic and political strategies around the world, the education on environmental issues is considered essential and should be promoted at early ages.

The aim of this article was to present a prototype of a pedagogical model for Education for Environmental Citizenship for primary education, based on a systematic survey of the available literature, whose objective is to develop informed, and conscious environmental citizens, enhancing their active participation in political and socio-environmental issues. According to the analyzed literature, the learning outcomes considered important for environmental citizenship that can be developed in primary school students are awareness and consciousness, knowledge, rights, duties, critical thinking, ethics, respect, responsibility, and empowerment.

To achieve the learning outcomes previously listed, some active, socio-constructivist, and student-centered methodologies can be applied and combined into a pedagogical model to maximize their effectiveness as follows: collaborative learning, play-based learning, critical inquiry learning, community-oriented learning, contemplative learning, outdoor learning, nature-based solutions learning, and socio-emotional learning. This pedagogical model has the potential to develop in students the ability to think critically, make informed and conscious decisions, and enhance active participation, leading to changes in society related to socio-environmental problems.

The activities must be selected and developed by the students according to the local or global socio-environmental problems they would like to address through their actions. All activities should be realistic and based on concrete situations, allowing students to develop and apply knowledge to situations and problems they consider socially relevant.

This prototype includes seven (7) stages that the authors consider to be necessary at least to structure the activities proposed, as follows: exploring the environment; questioning problems and searching contents; explaining facts and structuring ideas; proposing solutions; elaborating and communicating actions; reflecting and evaluating. The stages are not in a linear sequence, and the entry point can be any of the seven. When these stages are applied together with the methodologies and the activities proposed, it is expected that students develop the characteristics of an environmental citizen and manifest good practices of environmental citizenship. 
Figure 6 shows a resumed scheme with the design of the prototype for Education for Environmental Citizenship in primary education.

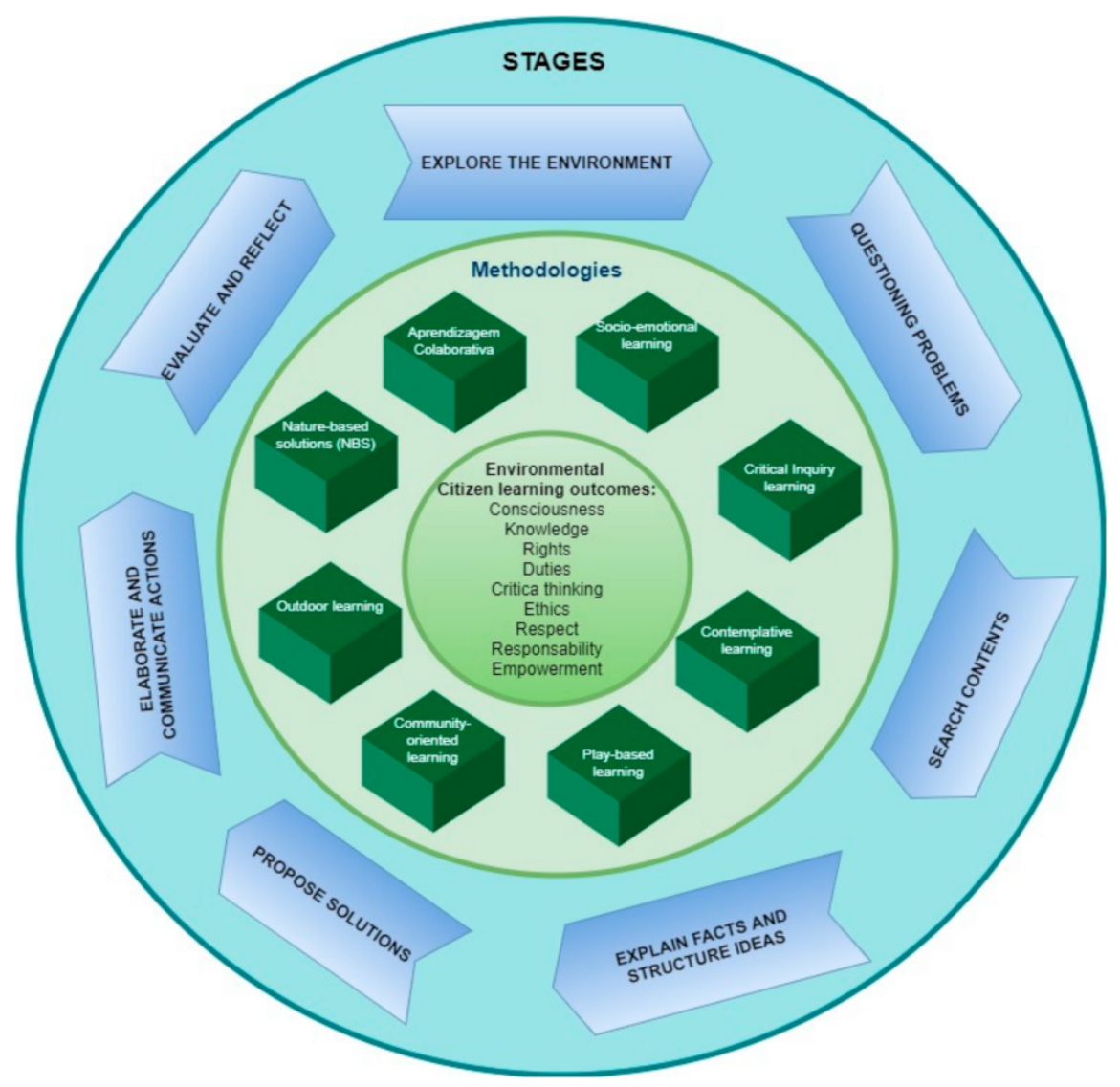

Figure 6. Prototype design of a pedagogical model for Education for Environmental Citizenship in primary education.

It is intended that this prototype can represent a guide for the implementation of methodologies for Education for Environmental Citizenship in primary education. This prototype continues to be an object of improvement and discussion through interactions with primary education specialists, environmental education specialists, and government and NGO bodies. Possible limitations from this model will be scrutinized and criticized by the experts (on environmental education or education for sustainability, on primary education, and primary school teachers) involved in the next development cycles of this DBR study, allowing for the improvement of this pedagogical model for Education for Environmental Citizenship in primary education.

Author Contributions: Conceptualization, T.M. and P.R.; methodology, T.M. and P.R.; data analyses, T.M.; writing — original draft preparation, T.M.; writing—review and editing, P.R. All authors have read and agreed to the published version of the manuscript.

Funding: This research was funded by a PhD fellowship from FCT-Portuguese Foundation for Science and Technology, grant number 2020.05059.BD.

Conflicts of Interest: The authors declare no conflict of interest. 


\section{References}

1. Hadjichambis, A.C.; Reis, P. Introduction to the Conceptualisation of Environmental Citizenship for Twenty First Century Education. In Conceptualizing Environmental Citizenship for 21st Century Education; Hadjichambis, A.C., Reis, P., Par-askevaHadjichambi, D., Činčera, J., Pauw, J.B., Gericke, N., Knippels, M.C., Eds.; Springer: Cham, Switzerland, 2020; Volume 4, pp. 17-28.

2. Cutter-Mackenzie, A.N.; Smith, R. Ecological literacy: The 'missing paradigm' in environmental education (part one). Environ. Educ. Res. 2003, 9, 497-524. [CrossRef]

3. Liefländer, A.K.; Fröhlich, G.; Bogner, F.X.; Schultz, P.W. Promoting connectedness with nature through environmental education. Environ. Educ. Res. 2013, 19, 370-384. [CrossRef]

4. Amaral, C.; Linhares, E. Educação em Ciências para a Cidadania: Práticas de ativismo com alunos do 1. CEB. Santarém: ESE do IPS. In Proceedings of the XVII Encontro Nacional de Educação em Ciências, XVII ENEC, I Seminário Internacional de Educação em Ciências, Santarém, Portugal, 14-16 September 2017.

5. Pedroso, J.V. Referencial de Educação Ambiental para a Sustentabilidade para a Educação Pré-Escolar, o Ensino Básico e o Ensino Secundário; Direção Geral de Educação: Santarem, Portugal, 2018.

6. Otto, S.; Evans, G.W.; Moon, M.J.; Kaiser, F.G. The development of children's environmental attitude and behavior. Glob. Environ. Chang. 2019, 58, 58. [CrossRef]

7. $\quad$ Činčera, J.; Romero-Ariza, M.; Zabiac, M.; Kalaitzidaki, M.; Bedmar, M.C.D. Environmental Citizenship in Primary Formal Education. In Conceptualizing Environmental Citizenship for 21st Century Education; Hadjichambis, A.C., Reis, P., Par-askevaHadjichambi, D., Činčera, J., Pauw, J.B., Knippels, M.C., Eds.; Springer: Cham, Switzerland, 2020; Volume 4, pp. $163-178$.

8. Hadjichambis, A.C.; Reis, P.; Paraskeva-Hadjichambi, D.; Činčera, J.; Pauw, J.B.; Gericke, N.; Knippels, M.C. Conceptualizing Environmental Citizenship for 21st Century Education; Springer: Cham, Switzerland, 2020.

9. So, W.W.M.; Chow, S.C.F. Environmental education in primary schools: A case study with plastic resources and recycling. Educ. 3-13 2019, 47, 652-663. [CrossRef]

10. Farmer, J.; Knapp, D.; Benton, G.M. An Elementary School Environmental Education Field Trip: Long-Term Effects on Ecological and Environmental Knowledge and Attitude Development. J. Environ. Educ. 2007, 38, 33-42. [CrossRef]

11. Marpa, E. Navigating Environmental Education Practices to Promote Environmental Awareness and Education. Int. J. Stud. Educ. 2020, 2, 45-57. [CrossRef]

12. Chawla, L. Nature-based learning for student achievement and ecological citizenship. Curric. Teach. Dialogue 2018, $20,25-39$.

13. Dean, H. Green Citizenship. Soc. Policy Adm. 2001, 35, 490-505. [CrossRef]

14. Stern, P.C.; Dietz, T.; Abel, T.; Guagnano, G.A.; Kalof, L. A Value-Belief-Norm Theory of Support for Social Movements: The Case of Environmentalism. Hum. Ecol. Rev. 1999, 6, 81.

15. Gleitman, H.; Fridlund, A.J.; Reisberg, D. Psicologia; Fundação Calouste Gulbenkian: Lisboa, Portugal, 2014.

16. Collado, S.; Rosa, C.; Corraliza, J. The Effect of a Nature-Based Environmental Education Program on Children's Environmental Attitudes and Behaviors: A Randomized Experiment with Primary Schools. Sustainability 2020, 12, 6817. [CrossRef]

17. Leopold, A. A Sand County Almanac, and Sketches Here and There; Oxford University Press: New York, NY, USA, 1949.

18. York, R.A. Re-Connecting with Nature: Transformative Environmental Education through the Arts. Ph.D. Thesis, University of Toronto, Toronto, TO, Canada, 2014.

19. Arnold, C.J.; Bogner, F.X. How green attitudes predict acquisition of different cognitive knowledge-types. In Proceedings of the 11th Conference of the European Science Education Research Association (ESERA), Helsinki, Finland, 31 August-4 September 2015.

20. Louv, R. The Nature Principle: Reconnecting with Life in a Virtual Age; Algonquin Books: Chapel Hill, NC, USA, 2012.

21. Cho, Y.; Lee, D. 'Love honey, hate honey bees': Reviving biophilia of elementary school students through environmental education program. Environ. Educ. Res. 2016, 24, 445-460. [CrossRef]

22. Conceição, T.; Baptista, M.; Reis, P. La contaminación de los recursos hídricos como punto de partida para el activismo so-ciocientífico. Rev. Eureka Sobre Enseñanza Divulg. Cienc. 2019, 16, 1502.

23. Baptista, M.; Reis, P.; de Andrade, V. Let's save the bees! An environmental activism initiative in elementary school. Vis. Sustain. 2018, 9, 41-48.

24. Jiménez-Liso, M.R.; González-Herrera, M.; Banos-González, I. Socio-Ecological Controversies in the News as Trigger of a ModelBased Inquiry Instructional Sequence about the Effect of Global Warming on the Great Barrier Reef. Sustainability 2020, $12,4676$. [CrossRef]

25. Reis, P.; Tinoca, L.; Baptista, M.; Linhares, E. The Impact of Student-Curated Exhibitions about Socio-Scientific Issues on Stu-dents' Perceptions regarding their Competences and the Science Classes. Sustainability 2020, 12, 2796. [CrossRef]

26. Dobson, A. Environmental sustainability: A view from the terraces. Environ. Politi. 1997, 6, 176-179. [CrossRef]

27. Dobson, A. Citizenship and the Environment; Oxford University Press: Oxford, UK, 2003.

28. Dobson, A. Environmental citizenship: Towards sustainable development. Sustain. Dev. 2007, 15, 276-285. [CrossRef]

29. Freeman, T.W.; O’Riordan, T. Environmentalism. Geogr. J. 1978, 144, 337. [CrossRef]

30. Pallett, H. Environmental Citizenship. Pre-Submission Version of Chapter in 'The International Encyclopedia of Geography: People, the Earth, Environment, and Technology; Douglas, R., Castree, N., Goodchild, M.F., Kobayashi, A., Liu, W., Marston, R.A., Eds.; Wiley Blackwell: Hoboken, NJ, USA, 2017.

31. Taylor, P.W. The Ethics of Respect for Nature. Environ. Ethic 1981, 3, 197-218. [CrossRef] 
32. Asah, S.; Bengston, D.N.; Westphal, L.M.; Gowan, C.H. Mechanisms of Children'sExposure to Nature: Predicting Adulthood Environmental Citizenship and Commitment to Nature-Based Activities. Environ. Behav. 2018, 50, 807-836. [CrossRef]

33. Hodson, D. Becoming part of the solution: Learning about activism, learning through activism, learning from activism. In Activist Science and Technology Education; Bencze, J.L., Alsop, S., Eds.; Springer: New York, NY, USA, 2014; pp. 67-98.

34. Cheng, J.; Monroe, M. Connection to Nature: Children's Affective Attitude Toward Nature. Environ. Behav. 2012, 44, 31-49. [CrossRef]

35. Wattchow, B.; Brown, M. Pedagogy of Place; Monash University Publishing: Victoria, BC, Canada, 2011.

36. Lloyd, A.; Gray, T. Place-based outdoor learning and environmental sustainability within Australian Primary Schools. J. Sustain. Educ. 2014. Available online: http://www.jsedimensions.org/wordpress/wp-content/uploads/2014/10/ AmandaLloydToniaGrayPDFReady.pdf (accessed on 29 April 2020).

37. Frick, J.; Kaiser, F.G.; Wilson, M. Environmental knowledge and conservation behavior: Exploring prevalence and structure in a representative sample. Pers. Individ. Differ. 2004, 37, 1597-1613. [CrossRef]

38. Colucci-Gray, L.; Camino, E.; Barbiero, G.; Gray, D. From scientific literacy to sustainability literacy: An ecological framework for education. Sci. Educ. 2006, 90, 227-252. [CrossRef]

39. Freire, P. The Pedagogy of the Oppressed; Alley Cat Editions: New York, NY, USA, 2000.

40. Hawthorne, M.; Alabaster, T. Citizen 2000: Development of a model of environmental citizenship. Glob. Environ. Chang. 1999, 9 , 25-43. [CrossRef]

41. Berkowitz, A.R.; Ford, M.E.; Brewer, C.A. A Framework for Integrating Ecological Literacy, In Environmental Education and Advocacy: Changing Perspectives of Ecology and Education; Cambridge University Press: Cambridge, UK, 2005; pp. 227-266.

42. Schild, R. Environmental citizenship: What can political theory contribute to environmental education practice? J. Environ. Educ. 2016, 47, 19-34. [CrossRef]

43. Sprinthall, N.A.; Sprinthall, R.C. Psicologia Educacional; Uma Abordagem Desenvolvimentista; McGrawHill: New York, NY, USA, 1993.

44. Bonnett, M.; Williams, J. Environmental Education and Primary Children's Attitudes towards Nature and the Environment. Camb. J. Educ. 1998, 28, 159-174. [CrossRef]

45. Griffin, S.L. The Effects of an Adolescent Apprenticeship Process in Environmental Education on the Development of Citizen Participation Characteristics in High School Seniors. Ph.D. Thesis, University of Massachusetts, Amherst, MA, USA, September 1982.

46. Marques, A.; Reis, P. Ativismo coletivo fundamentado em investigação através da produção e divulgação de vodcasts sobre poluição ambiental no 8. ano de escolaridade. Investig. Práticas 2015, 7, 5-21.

47. Baldwin, A. Vital ecosystem security: Emergence, circulation, and the biopolitical environmental citizen. Geoforum $2013,45,52-61$. [CrossRef]

48. Horton, D. Demonstrating environmental citizenship? A Study of Everyday Life among Green Activists. In Environmental Citizenship; The MIT Press: London, UK, 2006.

49. Smith, G.A. Response to Environmental Education: Promise and Performance. Can. J. Environ. Educ. 1998, 3, 48-55. Available online: https:/ / cjee.lakeheadu.ca/article/viewFile/334/286 (accessed on 28 April 2020).

50. Barry, J. Green Political Theory: Nature, Virtue, and Progress. Ph.D. Thesis, University of Glasgow, Glasgow, UK, 1996. Available online: http:/ / theses.gla.ac.uk/1523/1/1996barryphd.pdf (accessed on 28 April 2020).

51. European Network for Environmental Citizenship-ENEC. Defining “Environmental Citizenship". Available online: http: / / enec-cost.eu/our-approach/enec-environmental-citizenship/ (accessed on 15 April 2020).

52. Schutz, A. Empowerment: A Primer; Routledge Focus: New York, NY, USA, 2019.

53. Marques, A.R.; Reis, P. Producción y difusión de vídeos digitales sobre contaminación ambiental. Estudio de caso: Activismo colectivo basado en la investigación. Rev. Eureka Sobre Enseñanza Divulg. Cienc. 2017, 14, 215-226. [CrossRef]

54. Reis, P. Environmental Citizenship \& Youth Activism. In Conceptualizing Environmental Citizenship for 21st Century Education; Hadjichambis; Springer: Cham, Switzerland, 2020; pp. 139-148.

55. Reis, P.; Tinoca, L. A avaliação do impacto do projeto "We Act" nas percepções dos alunos acerca das suas competências de ação sociopolítica. Revista Brasileira de Ensino de Ciência e Tecnologia 2018, 11, $214-231$.

56. Gadotti, M. Pedagogia da Terra e Cultura da Sustentabilidade. Rev. Lusofona Educ. 2005, 6, 15-29.

57. Jensen, B.B. Knowledge, Action and Pro-environmental Behaviour. Environ. Educ. Res. 2002, 8, 325-334. [CrossRef]

58. Reynolds, J.M.; Hancock, D.R. Problem-based learning in a higher education environmental biotechnology course. Innov. Educ. Teach. Int. 2010, 47, 175-186. [CrossRef]

59. Dahlgren, M.A.; Öberg, G. Questioning to learn and learning to question: Structure and function of problem-based learning scenarios in environmental science education. High. Educ. 2001, 41, 263-282. [CrossRef]

60. Vasconcelos, C. Teaching Environmental Education through PBL: Evaluation of a Teaching Intervention Program. Res. Sci. Educ. 2010, 42, 219-232. [CrossRef]

61. Boavida, A.M.; Ponte, J.P. Investigação Colaborativa: Potencialidades e Problemas. In GTI (Org), Reflectir e Investigar Sobre a Prática Professional; APM: Lisbon, Portugal, 2002; pp. 43-55.

62. Laal, M.; Ghodsi, S.M. Benefits of collaborative learning. Procedia Soc. Behav. Sci. 2012, 31, 486-490. [CrossRef]

63. Welch, M. Collaboration: Staying on the Bandwagon. J. Teach. Educ. 1998, 49, 26-37. [CrossRef] 
64. Ucan, S. Changes in primary school students' use of self and social forms of regulation of learning across collaborative inquiry activities. Int. J. Educ. Res. 2017, 85, 51-67. [CrossRef]

65. Emotion in Education; Elsevier BV: Amsterdam, The Netherlands, 2007; pp. 37-56.

66. International Handbook of Emotions in Education. Int. Handb. Emot. Educ. 2014, 16, 1-10. [CrossRef]

67. Yang, C.; Bear, G.G.; May, H. Multilevel Associations Between School-Wide Social-Emotional Learning Approach and Student Engagement Across Elementary, Middle, and High Schools. Sch. Psychol. Rev. 2018, 47, 45-61. [CrossRef]

68. Ainley, M.; Corrigan, M.; Richardson, N. Students, tasks and emotions: Identifying the contribution of emotions to students' reading of popular culture and popular science texts. Learn. Instr. 2005, 15, 433-447. [CrossRef]

69. Assor, A.; Kaplan, H.; Kanat-Maymon, Y.; Roth, G. Directly controlling teacher behaviors as predictors of poor motivation and engagement in girls and boys: The role of anger and anxiety. Learn. Instr. 2005, 15, 397-413. [CrossRef]

70. Pekrun, R.; Frenzel, A.C.; Goetz, T.; Perry, R.P. The Control-Value Theory of Achievement Emotions. In Emotion in Education; Elsevier BV: Amsterdam, The Netherlands, 2007; pp. 13-36.

71. Collaborative for Academic, Social, and Emotional Learning. Safe and Sound: An Educational Leader's Guide to Evidence-Based Social and Emotional Learning Programs; CASEL: Chicago, IL, USA, 2005.

72. Martins, I.P.; Tenreiro-Vieira, C.; Vieira, R.; Sá, P.; Rodrigues, A.V.; Teixeira, F.; Couceiro, F.; Veiga, M.L.; Neves, C. Avaliação do Impacte do Programa de Formação em Ensino Experimental das Ciências: Um estudo de âmbito nacional-Relatório Final. Ministério da Educação e Ciência, Direção Geral de Educação, 2012. Available online: https:/ / www.dge.mec.pt/avaliacao-doimpacte-do-programa-de-formacao-em-ensino-experimental-das-ciencias-relatorio-final (accessed on 5 May 2020).

73. Bai, H. Beyond Educated Mind: Towards a Pedagogy of Mindfulness. In Unfolding Bodymind: Exploring Possibilities Through Education; The Foundation for Educational Renewall: Brandon, VT, USA, 2001.

74. Kaufman, P. Critical Contemplative Pedagogy. Radic. Pedag. 2017, 14. Available online: https://www.academia.edu/31097956 /Critical_Contemplative_Pedagogy (accessed on 18 December 2020).

75. Bonnett, M. Environmental education and the issue of nature. J. Curric. Stud. 2007, 39, 707-721. [CrossRef]

76. López-Azuaga, R.; Riveiro, J.M.S. Perceptions of inclusive education in schools delivering teaching through learning communities and service-learning. Int. J. Incl. Educ. 2018, 24, 1019-1033. [CrossRef]

77. The best of both worlds: A critical pedagogy of place. Environ. Educ. Res. 2008, 14, 308-324. [CrossRef]

78. Kelly, D.; Pelech, S. A Critical Conceptualization of Place-Conscious Pedagogy. Eur. J. Curric. Stud. $2019,5,732-741$.

79. Weisberg, D.S.; Hirsh-Pasek, K.; Golinkoff, R.M. Guided Play: Where Curricular Goals Meet a Playful Pedagogy. Mind Brain Educ. 2013, 7, 104-112. [CrossRef]

80. Weisberg, D.S.; Zosh, J.M.; Hirsh-Pasek, K.; Golinkoff, R.M. Talking it up: Play, language development, and the role of adult support. Am. J. Play 2013, 6, 39-54.

81. Robertson, N.; Morrissey, A.M.; Rouse, E. Play-based learning can set your child up for success at school and beyond. Sci. Educ. News 2018, 67, 50-51.

82. Ajiboye, J.O.; Olatundun, S.A. Impact of Some Environmental Education Outdoor Activities on Nigerian Primary School Pupils Environmental Knowledge. Appl. Environ. Educ. Commun. 2010, 9, 149-158. [CrossRef]

83. Amini, R. Outdoor based environmental education learning and Its effect in caring attitude toward environment. Indones. J. Sci. Educ. 2015, 4, 43-47. [CrossRef]

84. Brookes, A. Outdoor Education: Environmental Education reivented, or Environmental Education reconceived? Aust. J. En-viron. Educ. 1989, 5, 15-23. [CrossRef]

85. Szczytko, R.; Carrier, S.J.; Stevenson, K.T. Impacts of Outdoor Environmental Education on Teacher Reports of Attention, Behavior, and Learning Outcomes for Students with Emotional, Cognitive, and Behavioral Disabilities. Front. Educ. 2018, 3, 3. [CrossRef]

86. Otto, S.; Pensini, P. Nature-based environmental education of children: Environmental knowledge and connectedness to nature, together, are related to ecological behaviour. Glob. Environ. Chang. 2017, 47, 88-94. [CrossRef]

87. Kuo, M.; Barnes, M.; Jordan, C. Do Experiences With Nature Promote Learning? Converging Evidence of a Cause-and-Effect Relationship. Front. Psychol. 2019, 10, 305. [CrossRef]

88. Europeen Commission. Towards an EU Research and Innovation Policy Agenda for Nature-Based Solutions E Re-Naturing Cities; Europeen Commission: Bruxelles, Belgium, 2015.

89. European Schoolnet Academy. Nature-Based Solutions Learning Scenario: Let's Make our School a Growing Place. Available online: http: / / www.scientix.eu/resources / details?resourceId=28169 (accessed on 5 February 2021).

90. European Schoolnet Academy. Nature-Based Solutions Learning Scenario: Nature Changing Our Surroundings. Available online: http: / / www.scientix.eu/resources / details?resourceId=28167 (accessed on 5 February 2021).

91. European Schoolnet Academy. Nature-Based Solutions Learning Scenario: Nature-Based Solutions (NBS) for Climate Mitigation and Adaptation. Available online: http:/ / www.scientix.eu/resources/details?resourceId=28158 (accessed on 5 February 2021).

92. European Schoolnet Academy. Nature-Based Solutions Learning Scenario: The Travelling Fox. Available online: http://www. scientix.eu/resources / details?resourceId=28161 (accessed on 5 February 2021).

93. Hadjichambis, A.C.; Paraskeva-Hadjichambi, D. Education for Environmental Citizenship: The Pedagogical Approach. In Conceptualizing Environmental Citizenship for 21st Century Education; Springer: Cham, Switzerland, 2020; Volume 4, pp. $237-261$.

94. Sauvé, L. Environmental Education and Sustainable Development: A Further Appraisal. Can. J. Environ. Educ. 1996, 1, 7-13.

95. Orr, D.W. Environmental Education and Ecological literacy. Educ. Dig. 1990, 55, 49-53. 
96. Berkowitz, A.R.; Ford, M.E.; Brewer, C.A. A framework for integrating ecological literacy, civics literacy, and environmental citizenship in environmental education. Environ. Educ. Advocacy Chang. Perspect. Ecol. Educ. 2005, 277-366.

97. Hailwood, S. Environmental Citizenship as Reasonable Citizenship. Environ. Politi. 2005, 14, 195-210. [CrossRef]

98. Carlsson, M.; Jensen, B.B. Encouraging Environmental Citizenship: The Roles and Challenges for Schools. In Environmental Citizenship; The MIT Press: Cambridge, MA, USA, 2006; pp. 237-261.

99. Gough, S.; Scott, W. Promoting Environmental Citizenship Through Learning: Toward a Theory of Change. In Environmental Citizenship; The MIT Press: Cambridge, MA, USA, 2006; p. 263285.

100. Tidball, K.G.; Krasny, M.E. Toward an ecology of environmental education and learning. Ecosphere 2011, 2, 2. [CrossRef]

101. Sipos, Y.; Battisti, B.; Grimm, K. Achieving transformative sustainability learning: Engaging head, hands and heart. Int. J. Sustain. High. Educ. 2008, 9, 68-86. [CrossRef]

102. Kioupi, V.; Voulvoulis, N. Education for Sustainable Development: A Systemic Framework for Connecting the SDGs to Educational Outcomes. Sustainability 2019, 11, 6104. [CrossRef]

103. Arslan, S. The Influence of Environment Education on Critical Thinking and Environmental Attitude. Procedia Soc. Behav. Sci. 2012, 55, 902-909. [CrossRef]

104. Johnson, D.W.; Johnson, R.T.; Smith, K. The State of Cooperative Learning in Postsecondary and Professional Settings. Educ. Psychol. Rev. 2007, 19, 15-29. [CrossRef]

105. Johnson, D.W.; Johnson, R.T. Making cooperative learning work. Theory Pract. 1999, 38, 67-73. [CrossRef]

106. Le, H.; Janssen, J.; Wubbels, T. Collaborative learning practices: Teacher and student perceived obstacles to effective student collaboration. Camb. J. Educ. 2016, 48, 103-122. [CrossRef]

107. Panitz, T. Collaborative versus Cooperative Learning: A Comparison of the Two Concepts Which Will Help Us Understand the Un-Derlying Nature of Interactive Learning; Cape Cod Community College: Cape Cod, MA, USA, 1999.

108. Slavin, R.E. Research on Cooperative Learning and Achievement: What We Know, What We Need to Know. Contemp. Educ. Psychol. 1996, 21, 43-69. [CrossRef]

109. Young, D. Innovative Pedagogies for Preprimary and Early Grade Primary Education Programmes; UNESCO: Bangkok, Thailand, 2015.

110. Chu, S.K.W.; Reynolds, R.B.; Tavares, N.J.; Notari, M.; Lee, C.W.Y. 21st Century Skills Development Through Inquiry-Based Learning: From Theory to Practice; Springer: Hong Kong, China, 2016.

111. Durlak, J.A.; Weissberg, R.P.; Dymnicki, A.B.; Taylor, R.D.; Schellinger, K.B. The Impact of Enhancing Students' Social and Emotional Learning: A Meta-Analysis of School-Based Universal Interventions. Child. Dev. 2011, 82, 405-432. [CrossRef]

112. Fisak, B.J.; Richard, D.; Mann, A. The Prevention of Child and Adolescent Anxiety: A Meta-analytic Review. Prev. Sci. 2011, 12, 255-268. [CrossRef]

113. Lock, S.; Barrett, P.M. A Longitudinal Study of Developmental Differences in Universal Preventive Intervention for Child Anxiety. Behav. Chang. 2003, 20, 183-199. [CrossRef]

114. Li, Y.; Lynch, A.D.; Kalvin, C.; Liu, J.; Lerner, R.M. Peer relationships as a context for the development of school engagement during early adolescence. Int. J. Behav. Dev. 2011, 35, 329-342. [CrossRef]

115. Wong, A.S.; Li-Tsang, C.W.; Siu, A.M. Effect of a Social Emotional Learning Programme for Primary School Students. Hong Kong J. Occup. Ther. 2014, 24, 56-63. [CrossRef]

116. Rocard, M.; Csermely, P.; Jorde, D.; Lenzen, D.; Walberg-Henriksson, H.; Hemmo, V. Science Education Now: A Renewed Pedagogy for the Future of Europe; European Commission: Brussels, Belgium, 2007.

117. Tavares, R.; Almeida, P. Metodologia Inquiry Based Science Education no 1.e 2. CEB com recurso a dispositivos móveis uma revisão crítica de casos práticos. Educ. Formação Tecn. 2015, 8, 28-41.

118. Barbezat, D.P.; Bush, M. Contemplative Practices in Higher Education: Powerful Methods to Transform Teaching and Learning; Jossey-Bass: San Francisco, CA, USA, 2014.

119. Grossenbacher, P.G.; Parkin, S.S. Joining Hearts and Minds: A Contemplative Approach to Holistic Education in Psychology. J. Coll. Character 2006, 7, 1-13. [CrossRef]

120. Roeser, R.W.; Peck, S.C. An Education in Awareness: Self, Motivation, and Self-Regulated Learning in Contemplative Perspective. Educ. Psychol. 2009, 44, 119-136. [CrossRef] [PubMed]

121. Waters, L.; Barsky, A.; Ridd, A.; Allen, K.-A. Contemplative Education: A Systematic, Evidence-Based Review of the effect of Meditation Interventions in Schools. Educ. Psychol. Rev. 2015, 27, 103-134. [CrossRef]

122. Zajonc, A.G. Contemplative Pedagogy: A Quiet Revolution in Higher Education. New Dir. Teach. Learn. 2013, 2013, 83-94. [CrossRef]

123. Bai, H.; Scutt, G. Touching the Earth with the Heart of Enlightened Mind: The Buddhist Practice of Mindfulness for Environmental Education. Can. J. Environ. Educ. 2009, 14, 92-106.

124. Pulkki, J.; Dahlin, B.; Värri, V.-M. Environmental Education as a Lived-Body Practice? A Contemplative Pedagogy Perspective. J. Philos. Educ. 2016, 51, 214-229. [CrossRef]

125. Badiner, A.H. Mindfulness in the Marketplace: Compassionate Responses to Consumerism; Parallax Press: Berkeley, CA, USA, 2002.

126. Barnes, M.E. Encouraging interaction and striving for reciprocity: The challenges of community-engaged projects in teacher education. Teach. Teach. Educ. 2017, 68, 220-231. [CrossRef]

127. Gruenewald, D.A. Foundations of Place: A Multidisciplinary Framework for Place-Conscious Education. Am. Educ. Res. J. 2003, 40, 619-654. [CrossRef] 
128. Woodhouse, J.; Knapp, J. Place-Based Curriculum and Instruction: Outdoor and Environmental Education Approaches; Eric Digest: Charleston, WV, USA, 2000.

129. Sobel, D. Place-Based Education: Connecting Classrooms and Community; Orion Society Press: Great Barrington, MA, USA, 2004.

130. Schlottmann, C. Introduction: Place-based and Environmental Education. Ethic Place Environ. 2005, 8, 257-259. [CrossRef]

131. Tal, R.T. Community-based environmental education-a case study of teacher-parent collaboration. Environ. Educ. Res. 2004, 10, 523-543. [CrossRef]

132. Santos, M. A Importância do Jogo no $1^{\circ}$ Ciclo do Ensino Básico. Relatório final para obtenção do grau de Mestre; Instituto Politécnico de Coimbra: Coimbra, Portugal, 2018.

133. Wein, E.; Sutton-Smith, B. The Ambiguity of Play. J. Am. Folk. 2000, 113, 213. [CrossRef]

134. UNICEF. Learning Through Play. Strengthening Learning Through Play in Early Childhood Education Programes; The Lego Foundation: New York, NY, USA, 2018.

135. Roczen, N.; Kaiser, F.G.; Bogner, F.X.; Wilson, M. A Competence Model for Environmental Education. Environ. Behav. 2014, 46, 972-992. [CrossRef]

136. Ballantyne, R.; Packer, J. Nature-based Excursions: School Students' Perceptions of Learning in Natural Environments. Int. Res. Geogr. Environ. Educ. 2002, 11, 218-236. [CrossRef]

137. MacQuarrie, S.; Nugent, C.; Warden, C. Learning with nature and learning from others: Nature as setting and resource for early childhood education. J. Adventure Educ. Outdoor Learn. 2015, 15, 1-23. [CrossRef]

138. Prince, H. Experiential Environmental Education for Primary Aged Children; Eric Publications: Columbus, OH, USA, 1999.

139. Calliari, E.; Staccione, A.; Mysiak, J. An assessment framework for climate-proof nature-based solutions. Sci. Total. Environ. 2019, 656, 691-700. [CrossRef]

140. Geneletti, D. Promoting nature-based solutions for climate adaptation in cities through impact assessment. In Handbook on Biodiversity and Ecosystem Services in Impact Assessment; Edward Elgar Publishing: Cheltenham, UK, 2016; pp. 428-452.

141. Bybee, R.W.; Taylor, J.A.; Gardner, A.; Scotter, P.V.; Powell, J.C.; Westbrook, A.; Landes, N. The BSCS 5E Instructional Model: Origins, Effectiveness, and Applications; BSCS: Colorado Springs, CO, USA, 2006.

142. Free-choice environmental learning: Framing the discussion. Environ. Educ. Res. 2005, 11, 265-280. [CrossRef]

143. Hunter-Doniger, T. Seeing the forest through the trees: At the intersection of Forest Kindergartens and art-based environmental education. J. Adventure Educ. Outdoor Learn. 2020, 1-13. [CrossRef] 